\title{
Using the Casper Stent in Carotid Angioplasty: A Single Center Experience
}

\section{O uso do stent casper na angioplastia carotídea: Experiência de único centro}

\author{
Leandro José Haas ${ }^{1,20}$ Bernardo Przysiezny ${ }^{3}$ Thaize Regina Scramocin ${ }^{30}$ Natalia Tozzi Marques ${ }^{30}$ \\ Leticia Saori Tutida $^{3(-)}$ Marina Piquet Sarmento ${ }^{3(-)}$ Omar Ahmad Omar ${ }^{3}$ (i) Thais Moura Borille ${ }^{3 \text { (i) }}$ \\ Guilherme Voltolini Staedele ${ }^{3(0)}$ Liz Caroline de Oliveira Camilo ${ }^{3(0)}$ João Pedro Latronico Domingos ${ }^{3(0)}$ \\ Amanda Cristina Zimmermann ${ }^{3(-)}$ Evelyn Della Giustina $^{30}$
}

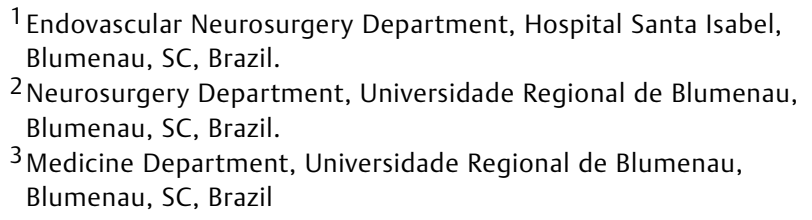

Address for correspondence Bernardo Przysiezny, medical student, Street Antonio da Veiga, 140-Itoupava Seca, Blumenau 89012580, Santa Catarina, Brazil (e-mail: beprzysiezny@gmail.com).

Arq Bras Neurocir 2022;41(1):e1-e6.

\begin{abstract}
Objectives To establish the success rate in endovascular internal carotid artery (ICA) stenosis recanalization using the double-layer stent Casper-RX (Microvention, Inc 35 Enterprise, Aliso Viejo, California, United States of America) and to identify the main comorbidities in individuals with ICA stenosis, morphological characteristics of the stenosis, diagnostic methods, intraoperative complications, as well as morbidity and mortality within 30 days of the surgical procedure.

Materials and Methods Retrospective analysis of 116 patients undergoing ICA angioplasty with a degree of stenosis $\geq 70 \%$ using Casper-RX stenting who underwent this procedure from April 2015 to December 2019.

Results Technical success was achieved in $99.1 \%$ of the patients. Three of them had postprocedural complications: one transient ischemic attack (TIA) and two puncture site hematomas. A cerebral protection filter was not used in only two procedures, as these consisted of dissection of the carotid. There was satisfactory recanalization and

Keywords

- casper stent

- double-layer stent

- carotid stenosis

- angioplasty

- stroke adequate accommodation of the stents in the previously stenosed arteries, with no restenosis in $99.4 \%$ of the cases.

Conclusion The endovascular treatment of extracranial carotid stenoses using the Casper-RX stent showed good applicability and efficacy. Although only two cases of thromboembolic complications occurred during the procedure, further investigation and studies on the effectiveness of this new device are needed.
\end{abstract}

received

July 20, 2021

accepted

September 6, 2021

published online

January 4, 2022
DOI https://doi.org/ 10.1055/s-0041-1740405. ISSN 0103-5355.

\footnotetext{
(c) 2022. Sociedade Brasileira de Neurocirurgia. All rights reserved. This is an open access article published by Thieme under the terms of the Creative Commons Attribution-NonDerivative-NonCommercial-License, permitting copying and reproduction so long as the original work is given appropriate credit. Contents may not be used for commercial purposes, or adapted, remixed, transformed or built upon. (https://creativecommons.org/ licenses/by-nc-nd/4.0/)

Thieme Revinter Publicações Ltda., Rua do Matoso 170, Rio de Janeiro, RJ, CEP 20270-135, Brazil
} 


\section{Resumo}

Palavras-chave
- stent casper
- stent de dupla camada
- estenose carotídea
- angioplastia
- AVC

Objetivos Identificar a taxa de sucesso na recanalização de estenose da artéria carótida interna $(\mathrm{ACl})$ obtida por método endovascular quando utilizado o stent de dupla camada Casper-RX (Microvention, Inc 35 Enterprise, Aliso Viejo, California, United States of America) e identificar as principais comorbidades apresentadas pelos indivíduos com estenose de $\mathrm{ACl}$, características morfológicas das estenoses, métodos utilizados para diagnósticos, ocorrência de complicações transoperatórias e a morbimortalidade nos 30 dias posteriores ao procedimento cirúrgico.

Materiais e métodos Análise retrospectiva de 116 pacientes submetidos a procedimento de angioplastia da $\mathrm{ACl}$ com grau de estenose $\geq 70 \%$, com a utilização de stent Casper-RX, durante o período de abril de 2015 a dezembro de 2019.

Resultados O sucesso técnico foi alcançado em 99,1\% dos indivíduos. Três pacientes apresentaram complicações pós procedimento, sendo um acidente encefálico transitório (AIT) e dois hematomas de sítio de punção. Em apenas dois procedimentos não se utilizou filtro de proteção cerebral devido tratar-se de dissecção carotídea. Houve satisfatória recanalização e acomodação adequada dos stents nas artérias previamente estenosadas, não havendo reestenose em $99,4 \%$ dos casos.

Conclusão O tratamento endovascular das estenoses carotídeas extracranianas com uso do stent Casper-RX demonstrou boa aplicabilidade e eficácia. Apesar de ter apresentado apenas dois casos de complicações tromboembólicas durante o procedimento, são necessárias maiores investigações e estudos sobre a eficácia deste novo dispositivo.

\section{Introduction}

Extracranial stenosis of the internal carotid artery (ICA) accounts for between $\sim 10$ and $15 \%$ of ischemic strokes, which is one of the main causes of death and disability in the world. ${ }^{1}$ The advent of vascular microsurgery brought stent angioplasty as a promising alternative to ICA endarterectomy, especially for patients whose comorbidities increase their surgical risk, in cases of restenosis after procedures, and in those with previous radiation therapy of the cervical region. $^{2}$

Stenting of the carotid artery is associated with long-term lower rates of stroke after elective treatment of individuals with significant extracranial ICA stenosis. ${ }^{3}$ However, this technique poses a risk of intraoperative cerebral embolism due to mobilization of atherothrombotic materials after manipulation of the lesion, as well as to plaque protrusion through the expanded stent struts. For this reason, special attention has been paid to the design, material, and shape of the chosen stent. ${ }^{4}$

To reduce the embolic risk of the procedure, a dual-layer carotid stent model has been introduced. In addition to the self-expanding nitinol outer layer that provides support, its second micro mesh layer provides better plaque coverage while remaining flexible. ${ }^{5}$ Short-term outcomes following the use of these devices in elective environments have proven to be promising. ${ }^{6}$

The Casper-RX carotid stent has the smallest area between closed cells of all carotid stents on the market. Double-layer devices have delivered greater benefits regarding atheroma plaque coverage and decreased likelihood of infarction due to the embolization of atheroma plaques. ${ }^{7}$
Thus, the purpose of the present article is to study carotid artery stenosis recanalization using a new model of double-layer stent, the Casper-RX, as well as to evaluate its clinical behavior in a reference center for endovascular neurosurgery in Brazil.

\section{Methodology}

\section{Design and Sample}

Retrospective study of the medical records of 116 patients undergoing angioplasty of the extracranial segment of the ICA using the Casper-RX stent from April 2015 to December 2019 in a reference center service for endovascular neurosurgery in the city of Blumenau, state of Santa Catarina, Brazil.

\section{Inclusion and Exclusion Criteria}

Symptomatic and asymptomatic patients who underwent endovascular treatment of stenosis of at least $70 \%$ of the ICA with Casper-RX stent implantation from April 2015 to December 2019 were included. Insufficient data - such as segment loss within 30 days and absence of radiological reports - were considered exclusion criteria.

\section{Data Analysis}

Categorical variables were expressed as absolute values (percentages), and quantitative variables, as means \pm standard deviation (SD) or medians (interquartile range [IQR]) as appropriate. Analyses were tabulated in Microsoft Excel 2020 (Microsoft Corporation, Redmond, WA, USA) and analyzed using the SPSS Statistics for Windows version 17.0 (SPSS Inc., Chicago, IL, USA). Device safety and therapeutic success were evaluated, as well as the rate of complications and restenosis, compared with literature data. 


\section{Variables}

Epidemiological variables such as gender, age, and preexisting comorbidities - diabetes mellitus, hypertension, dyslipidemia, smoking, and heart disease were collected. Pretreatment symptoms included headache, dizziness, ischemic stroke, and transient ischemic attack (TIA). Regarding the carotid lesion, the degree of stenosis on the affected side, laterality, treated bilaterality, presence of dissection, ulcerated plaque, and contralateral occlusion were analyzed.

Regarding the surgical procedure, the access type (femoral or axillary), immediate therapeutic success, intra- and postoperative events - from 90 days up to 6 months -, use of a cerebral protection filter, and stent diameter were studied. The overall neurological outcome of the individuals was evaluated using the 90-day modified Rankin Scale (mRS). Technical success was evaluated by carotid Doppler ultrasonography (USG) at least 6 months after the endovascular intervention. According to the degree of stenosis, patients were divided into "absent stenosis" if $<30 \%$, "residual stenosis" if the persistence was between 30 and $40 \%$, and "late stenosis" if they presented a higher degree with onset after 6 months of follow-up. Stent occlusion was also analyzed.

The noninvasive preprocedural diagnostic methods used include magnetic resonance imaging (MRI), computed tomography (CT), magnetic resonance angiography, angiotomography, and carotid Doppler test. Regarding the invasive test, cerebral arteriography was used in all procedures during angioplasty.

\section{Procedure}

Patients undergoing endovascular intervention had atheromatous disease in the extracranial portion of the internal carotid artery, with a degree of stenosis between 70 and $99 \%$, were symptomatic, or had been incidentally diagnosed. They were first put under sedation and total heparinization $10,000 \mathrm{UI}$, with femoral intra-arterial instillation of low osmolarity nonionic contrast through a guide catheter. Then, cerebral angiographies were performed to identify the precise site of stenosis and its degree. Brain protection filters, such as Spider FX (Medtronic, 710 Medtronic Parkway, Minneapolis, MN, United States of America), AngioGuard (Cordis 5452 Betsy Ross Dr, Santa Clara, CA, United States of America), and EmPro (Microvention, Inc 35 Enterprise, Aliso Viejo, CA, United States of America) were inserted. The filter passed through the stenosis and was then deployed. The Casper-RX stents with diameters of between 7 and $9 \mathrm{~mm}$ adapted to the wall, which allowed total correction of the affected arteries. After mapping and real-time radioscopy, the stents were detached. The cerebral protection filters were removed, and postoperative angiographies were performed, showing full coverage of the plaques and correct device patency. The primary endpoint was achieved with the successful placement of the device.

\section{Antiplatelet Therapy}

Double antiplatelet therapy was administered with aspirin $200 \mathrm{mg}$ and clopidogrel $75 \mathrm{mg}$ to all patients, from 7 days before the procedure up to 3 months after the angioplasty.

\section{Results}

\section{Epidemiological Variables, Symptoms, and Comorbidities}

The mean age of the patients was 73 (66 to 79) years old; 79\% were $\geq 68$ years old. Of the total sample, $61.2 \%$ were male. Regarding the clinical presentation, 111 (96\%) were symptomatic, mainly with dizziness (59.5\% of the cases), ischemic stroke (33.6\%) and TIA (17.2\%). The most prevalent comorbidities were arterial hypertension (90.5\%), and dyslipidemia (94\%) (-Table 1).

Table 1 Epidemiological and clinical characteristics

\begin{tabular}{|c|c|}
\hline Characteristic & $\begin{array}{l}\text { All cases } \\
n=116\end{array}$ \\
\hline Age (years old) (mean [IQR]) & $73(66-79)$ \\
\hline$\geq 68$ years old $(n[\%])$ & $79(68.1)$ \\
\hline \multicolumn{2}{|l|}{ Gender ( $n[\%])$} \\
\hline Male & $71(61.2)$ \\
\hline Female & $45(38.8)$ \\
\hline \multicolumn{2}{|c|}{ Clinically documented symptoms ( $n[\%])$} \\
\hline Dizziness & 69 (59.5) \\
\hline Headache & $7(6)$ \\
\hline Ischemic stroke & $39(33.6)$ \\
\hline Transient ischemic attack & $20(17.2)$ \\
\hline \multicolumn{2}{|l|}{ Comorbidities (n [\%]) } \\
\hline Arterial hypertension & $105(90.5)$ \\
\hline Diabetes mellitus & $43(37.1)$ \\
\hline Current smoker & $29(25)$ \\
\hline Dyslipidemia & $109(94)$ \\
\hline Cardiopathy & $29(25)$ \\
\hline \multicolumn{2}{|c|}{ Stenosis in arteriography/Doppler } \\
\hline Degree (\%), mean (IQR) & $80(70-92.5)$ \\
\hline Ulceration (n [\%]) & $112(96.5)$ \\
\hline Carotid dissection (n [\%]) & $4(3.4)$ \\
\hline \multicolumn{2}{|l|}{ Side of occlusion ( $n[\%])$} \\
\hline Left & $62(53.5)$ \\
\hline Right & $54(46.5)$ \\
\hline \multicolumn{2}{|c|}{ Contralateral internal carotid artery $(n[\%])$} \\
\hline Occlusion & $10(8.6)$ \\
\hline Previous treatment & $10(8.6)$ \\
\hline \multicolumn{2}{|c|}{ Neuroimaging before procedure (n [\%]) } \\
\hline MRI & $21(18.1)$ \\
\hline CT scan & $27(23.3)$ \\
\hline Arteriography & $116(100)$ \\
\hline AngioMRI & $11(9.4)$ \\
\hline Angiotomography & $50(43.1)$ \\
\hline Carotid Doppler & $75(64.6)$ \\
\hline
\end{tabular}

Abbreviations: CT, computed tomography; IQR, interquartile range; MRI, magnetic resonance imaging. 


\section{Preprocedural Stenosis Characteristics}

Arteriography was the neuroimaging test of choice in all patients, allowing preoperative assessment of the degree of stenosis, of the presence of ulcerated plaque, and of dissecting pseudoaneurysm in the carotid arteries. Carotid Doppler test was performed in 75 individuals (64.6\%). Other imaging tests used are described in -Table 1. The average duration of the procedure was $\sim 30$ minutes.

\section{Technical Success and Intraoperative Complications}

The average diameter of the implanted devices was $8.0 \mathrm{~mm}$, with no need for additional stenting for complete coverage of the plaque. The surgical access was through the femoral artery in all patients. In 114 patients (98.3\%), a cerebral protection filter was used during the procedure, mostly AngioGuard (81\%), EmPro (13.8\%), and Spider (2.6\%). There were neither intra- nor postoperative complications in the two cases performed without a cerebral protection filter; therapeutic success was achieved, as these were dissection cases.

In 113 patients (97.4\%), Casper stents were successfully placed in the carotid artery. During the procedure, 1 patient $(0.8 \%)$ underwent a dissection of the internal iliac artery. One patient $(0.8 \%)$ had encephalic thromboembolic complications, which were promptly identified and treated with stenting and recanalization of the affected arterial segment. Another patient (0.8\%), who had a critical stenosis of $99 \%$, with calcified plaque and a kinking of the left internal carotid artery, had a rupture of the artery in the distal portion of the stent during balloon angioplasty; this was the only case of death during the procedure.

\section{Postoperative Complications}

In $97.4 \%$ of the cases, there were no complications after the surgical procedure (113/116). Among the events observed, 1 patient had TIA $(0.8 \%)$ and 2 had a hematoma at the puncture site (1.6\%), both treated conservatively.

There were 3 deaths, at 12,18, and 19 days after the procedure. There was no causal relationship between these late deaths and the endovascular intervention. This outcome is attributed to the intrinsic complications of the initial ischemic stroke - infectious disorders such as aspiration pneumonia and evolution toward multiple organ failure.

\section{Restenosis Control Follow-up and Modified Rankin Scale}

Throughout the clinical follow-up, a total of 115 patients (99.1\%) remained stenosis-free $(<30 \%)$ on imaging, whereas 1 patient $(0.8 \%)$ had residual stenosis (between 30 and $40 \%$ ). Up to the last evaluations, no patient developed carotid restenosis or device occlusion after implantation of the Casper stent.

- Table 2 shows the mRS after 90 days of follow-up. The mean $\mathrm{mRS}$ value after angioplasty was 0.38 , which points to the existence of reduced deficits in the functional evolution of the studied individuals.
Table 2 Outcomes and neuroimaging

\begin{tabular}{|l|l|}
\hline Characteristic & $\begin{array}{l}\text { All cases } \\
n=116\end{array}$ \\
\hline Immediate procedure success $(n[\%])$ & $115(99.1)$ \\
\hline Transprocedural events $(n[\%])$ & \\
\hline None & $113(97.4)$ \\
\hline Dissection of the internal iliac artery & $1(0.8)$ \\
\hline Thromboembolic complication & $1(0.8)$ \\
\hline Vascular rupture and death & $1(0.8)$ \\
\hline Technical success $(n[\%])$ & \\
\hline No stenosis $(<30 \%)$ & $115(99.1)$ \\
\hline Residual stenosis (30-40\%) & $1(0.8)$ \\
\hline Late restenosis & $0(0)$ \\
\hline Stent occlusion $(n[\%])$ & $0(0)$ \\
\hline Post procedural events (n [\%]) & \\
\hline None & $113(97.4)$ \\
\hline Minor stroke & $1(0.8)$ \\
\hline Groin hematoma at the puncture site & $2(1.6)$ \\
\hline mRS after 3 months (mean \pm SD) & $0.38 \pm 1.23$ \\
\hline $0(n$ [\%]) & $105(90.5)$ \\
\hline $1(n[\%])$ & $0(0)$ \\
\hline $2(n[\%])$ & $2(1.7)$ \\
\hline $4(n[\%])$ & $6(5.2)$ \\
\hline $5(n[\%])$ & $2(1.7)$ \\
\hline $6(n[\%])$ & $1(0.8)$ \\
\hline Late death $(n[\%])$ & 3() \\
\hline
\end{tabular}

Abbreviations: mRS, modified Rankin scale; SD, Standard deviation.

\section{Discussion}

Advances in neurointerventional techniques and the emergence of new endovascular materials have made stent angioplasty a safe and effective alternative for the treatment of carotid stenosis. Factors contributing to this evolution range from greater operator experience and selection of candidates for intervention to better device design. ${ }^{2}$ The present study reports the outcome of a case series performed in a reference center including 116 patients with asymptomatic (4\%) and symptomatic (96\%) carotid stenosis to evaluate the performance of the Casper-RX stent. As a primary endpoint, device placement was successfully completed in $97.4 \%$ of the cases, with no immediate intercurrences.

For a long time, arterial endarterectomy (AE) was the recommended therapy for carotid artery stenosis. ${ }^{8}$ Currently, carotid angioplasty is increasingly indicated. Both methods achieve the same revascularization success rates, a similar incidence of complications and of stroke in the shortand long-term. ${ }^{9}$ Patients $<70$ years old, as well as the symptomatic ones with severe stenosis and comorbidities that put them at high surgical risk, seem to benefit from angioplasty treatment. ${ }^{10,11}$ The current literature still favors 
endarterectomy as being overall safer and more effective. ${ }^{12}$ However, there is still much to learn about the feasibility and safety of stent systems used today.

A growing number of studies regarding this device supports its good performance and promising results in selected individuals. Mutzenbach et $\mathrm{al}^{13}{ }^{13}$ in a study of 138 patients who underwent angioplasty with Casper stenting, achieved full success in all cases, with no intraoperative technical failure or adverse neurological events reported within 90 days. Only $14.5 \%$ of the cases had residual stenosis (between 30 and 40\%) after the procedure. In the present study, were also found a high rate of surgical success and few intraoperative complications when using Casper stents. After 90 days of follow-up, the neurological and functional outcome was favorable in most cases, with no deficits in $93.1 \%$ of the individuals assessed using the mRS scale. The rate of residual stenosis in the study population was even lower $(0.8 \%)$, and no cases of late restenosis or stent occlusion were recorded, which speaks in favor of the efficacy of the implanted device. The contribution of brain protection filters and of antiplatelet therapy for these outcomes should be considered.

In another study, in a sample of 110 severe carotid stenosis patients, the implantation of Casper stents combined with a distal embolic protection device was shown to be safe and to lead to a lower rate of ischemic lesions on diffusion-weighted MRI when compared with other stents, especially the conventional single-layer ones. ${ }^{14}$ Similarly, a reduced number of thromboembolic complications was observed in this study. During stent implantation, there was only one thromboembolic event, which was promptly reversed and did not cause any permanent neurological deficits. Throughout the follow-up of up to 6 months after the procedure, there was one case of TIA. Such an outcome may be attributed to the double nitinol layer and micro mesh, as well as to the closed-cell design, of the Casper stent. ${ }^{4}$ The other complications - late deaths, vascular rupture, internal iliac artery dissection, and puncture site hematoma - were not related to the device itself, but rather to the inherent risk of the procedure and to the underlying diseases of the patient.

In a study with a smaller sample size, Ozpeynirci et al. ${ }^{15}$ analyzed 29 patients who underwent ICA angioplasty using a Casper-RX stent, of whom $78.6 \%$ were male with a mean age was 71.7 years old. The authors report 6 adverse events in the perioperative period, including 1 stent occlusion (3.4\%), 2 patients with type 2 parenchymal hematoma (6.8\%), and 3 other patients (10.3\%) with a massive cerebral infarction area not related to a worse prognosis or to stent occlusion. No thromboembolic events were observed intraoperatively.

\section{Conclusion}

The outcomes achieved in the present study corroborate the efficacy and safety of the use of Casper-RX stents to treat ICA stenosis, as previously demonstrated in the literature. In this series, technical success was achieved, with good clinical repercussion and a low complication rate, considering the sample size. However, long-term follow-up is needed to better evaluate this new device, as well as comparative studies with other closed-cell stents.

\section{Ethics}

The present study was conducted according to the Standard Item Protocol: Recommendations for Interventions (SPIRIT) and was approved by the local ethics committee under CAEE 31685320.0.0000.5370. The Informed Consent Form (ICF) was presented and made available to all individuals in the study.

\section{Conflict of Interests}

The authors have no conflict of interests to declare.

\section{References}

$1 \mathrm{Jr}$ SD, Pauli EM. Clinical Algorithms in General Surgery. NY, USA: Springer Nature Switzerland; 2019:547-548

2 Clavel P, Hebert S, Saleme S, Mounayer C, Rouchaud A, Marin B. Cumulative incidence of restenosis in the endovascular treatment of extracranial carotid artery stenosis: a meta-analysis. J Neurointerv Surg 2019;11(09):916-923

3 Bonati LH, Dobson J, Featherstone RL, et al; International Carotid Stenting Study investigators. Long-term outcomes after stenting versus endarterectomy for treatment of symptomatic carotid stenosis: the International Carotid Stenting Study (ICSS) randomised trial. Lancet 2015;385 (9967):529-538

4 Broussalis E, Griessenauer C, Mutzenbach S, et al. Reduction of cerebral DWI lesion burden after carotid artery stenting using the CASPER stent system. J Neurointerv Surg 2019;11(01): 62-67

5 Nikas DN, Makos X, Umemoto T, et al. Update on new stents and protection devices for carotid artery stenting: what we know, what we learnt recently and what we need to know. J Cardiovasc Surg (Torino) 2017;58(01):13-24

6 Sannino A, Giugliano G, Toscano E, et al. Double layered stents for carotid angioplasty: A meta-analysis of available clinical data. Catheter Cardiovasc Interv 2018;91(04):751-757

7 Carnelli D, Pennati G, Villa T, Baglioni L, Reimers B, Migliavacca F. Mechanical properties of open-cell, self-expandable shape memory alloy carotid stents. Artif Organs 2011;35(01):74-80

8 Mantese VA, Timaran CH, Chiu D, Begg RJ, Brott TGCREST Investigators. The Carotid Revascularization Endarterectomy versus Stenting Trial (CREST): stenting versus carotid endarterectomy for carotid disease. Stroke 2010;41(10, Suppl):S31-S34

9 Spence JD, Naylor AR. Endarterectomy, Stenting, or Neither for Asymptomatic Carotid-Artery Stenosis. N Engl J Med 2016;374 (11):1087-1088

10 Brott TG, Hobson RW II, Howard G, et al; CREST Investigators. Stenting versus endarterectomy for treamtent of carotid-artery stenosis. N Engl J Med 2010 Jul 8;363(02):198

11 Ederle J, Dobson J, Featherstone RL, et al; International Carotid Stenting Study investigators. Carotid artery stenting compared with endarterectomy in patient with symptomatic carotid stenosis (International Carotid Stenting Study): an interim analysis of a randomised controlled trial. Lancet 2010 Jul 10;376 (9735):90

12 Luebke T, Brunkwall J. Carotid artery stenting versus carotid endarterectomy: updated meta-analysis, metaregression and trial sequential analysis of short-term and intermediate-to long-term outcomes of randomized trials. J Cardiovasc Surg (Torino) 2016;57(04):519-539 
6 Using the Casper stent in Carotid Angioplasty Haas et al.

13 Mutzenbach SJ, Millesi K, Roesler C, et al. The Casper Stent System for carotid artery stenosis. J Neurointerv Surg 2018;10(09):869-873

14 Müller MD, Lyrer P, Brown MM, Bonati LH. Carotid artery stenting versus endarterectomy for treatment of carotid artery stenosis. Cochrane Database Syst Rev 2020;2(02): CD000515
15 Ozpeynirci Y, Capatana C, Rosskopf J, Schmitz BL, Hamann GF, Braun M. Emergency carotid artery revascularization using Casper-RX stent: A single-center experience. Interv Neuroradiol 2020;26(04):433-438 